ON THE RECORD

"We used to be afraid

of comets. The

dinosaurs should have

been afraid of comets. Now it is the comet's turn to be afraid."

UCL space researcher Andrew Coates gets a little carried away describing NASA's Deep Impact mission, in

which a probe crashed into the

Tempel 1 comet (see page 13).

"The guidance offered in this article on how to anticipate, model and minimize a botulinum toxin attack can be valuable for biodefence."

Bruce Alberts, president of the US National Academy of Sciences, justifies publishing a paper model ling a bioterrorist attack with botulinum toxin.

\section{“If something bad} happens as a result of this, it's the Department of Health and Human Services who will have todeal with it, not the academy."

US health department spokesman MarcWolfson explains the agency's objections to the botulinum paper.

\section{SCORECARD}

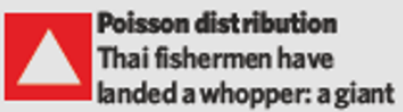
catfish tipping the scales at 293 kilograms. Making a splash as the largest freshwater fish on record, conservationists were keen for the behemoth to be set free.Sadly, it had already cashed itschips - cooked and eaten by itsproud captors.

Golden touch Isaac Newton's long-lost notes on alchemy have been found - but scholars are struggling to turn the written code into something they can read.

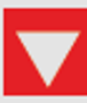
Hard to swallow Astudy finds that processed duck meat exported from China to Japan in 2003 contained bird fluvirus, giving rise to fears that it could be a threat to humanhealth.

\title{
Scientists finally get their hands on Kennewick man
}

\section{SAN DIEGO}

America's most highly contested anthropology specimen, Kennewick man, is finally being studied by scientists.

After nine years of federal-court battles and several months of preparation, researchers last month began examining the ancient skull and bones. The US government and Native American tribes had fought to block the bones' examination under a federal law designed to protect ancient human remains. But last year, the eight scientists involved won the legal battle.

The male skeleton was found in July 1996, along the banks of the Columbia River near Kennewick, Washington.

Preliminary radiocarbon dating suggests that Kennewick man lived about 9,300 calendar years ago. As there are so few full skeletons of New World individuals more than 8,000 years old, the researchers want to closely catalogue everything about the skeletal remains to try to work out who he was and where he came from. The bones will be inventoried and measured, and the skeleton reconstructed. It will then be checked for evidence of disease, trauma, diet and, with luck, DNA. The shape of the skull and the length of the arms and legs are also particularly valuable for deducing an individual's evolutionary history.

So far, key skeletal remains - particularly pieces of the skull - have been scanned using computerized tomography. The researchers aim to make a complete skull cast from the scan data to enable them to study the skull without disturbing the real bones too much. A stone blade or point encased in the pelvis has also been extensively scanned. The weapon is buried so deeply that the researchers can't identify its point or base, which could help to determine the weapon's heritage.

Douglas Owsley, head anthropologist at the Smithsonian Institution in Washington DC, who is leading some of the studies, says he is glad the work has finally begun. "I am really relieved," he says. "This is one of the most important specimens in the Americas."

But not all of the scientists who fought the case can take part in the work. The battle in federal court in Portland, Oregon, was so long that two of the eight scientists have retired, and a third, Robson Bonnichsen of Texas A\&M University in College Station, died in his sleep last December, aged 64 - just two weeks after getting a look at the specimen. "He was euphoric when he got to see it," says Cleone Hawkinson, a retired anthropologist from Portland who helps the group. Ironically, Bonnichsen had filed a court declaration in 2002 arguing for a quick decision because senior scientists in the group might not live to study the bones.

The dispute has also been financially costly. The federal government must pay the scientists' \$2.5-million legal costs, and the government's own costs are estimated at $\$ 6$ million. Rex Dalton

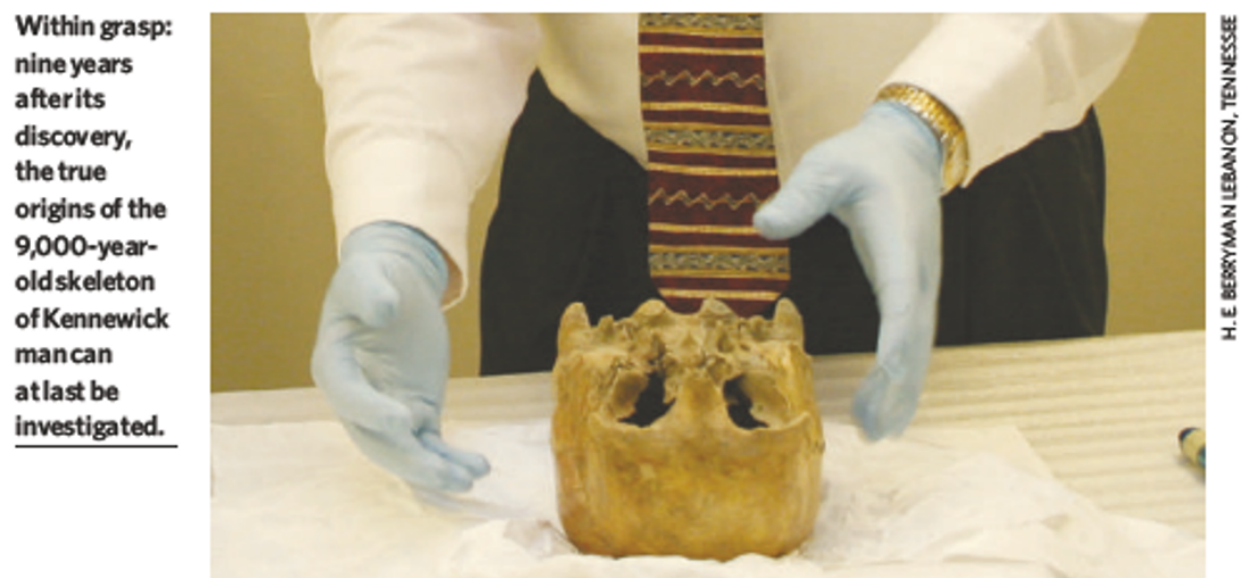

